\title{
PERANAN INSTITUSI PENDIDIKAN FORMAL DALAM PENCEGAHAN TINDAK KORUPSI DI INDONESIA
}

\author{
THE ROLE OF FORMAL EDUCATION INSTITUTIONS IN PREVENTION OF \\ CORRUPTION IN INDONESIA
}

\author{
Mochammad Faizal \\ Prodi S2 Manajemen, Fakultas Ekonomi dan Bisnis \\ Universitas Telkom, Bandung, Indonesia \\ hai@mf-chan.com \\ Rahmanita Budi Aisah \\ Prodi S1 Ilmu Komunikasi, Fakultas Komunikasi dan Bisnis \\ Universitas Telkom, Bandung, Indonesia \\ rahmanitabudiaisah@gmail.com
}

\begin{abstract}
Abstrak
Banyaknya kasus korupsi di Indonesia dapat ditemukan di berbagai sektor. Salah satu pemicu atas hal tersebut adalah rendahnya kesadaran bahwa masyarakat juga turut terlibat dalam praktik korupsi, baik sebagai korban maupun sebagai pelaku. Di lain sisi, pelajar sebagai bagian dari elemen masyarakat dan calon penerus bangsa memiliki pemahaman yang baik atas tindak korupsi di Indonesia. Artikel ini akan membahas bagaimana institusi pendidikan formal dapat mencegah dan menekan angka korupsi yang ada di masyarakat. Dari studi literatur yang telah dilakukan, didapat hasil bahwa sinergi antara institusi pendidikan dan para siswa dalam melakukan pendidikan anti korupsi dapat mencegah hadirnya praktik korupsi di masyarakat Indonesia, melalui berbagai metode yang menyesuaikan pada jenjang pendidikan dari siswa tersebut.
\end{abstract}

Kata kunci : korupsi di masyarakat, pendidikan anti korupsi, pendidikan formal, siswa

\begin{abstract}
Many cases of corruption in Indonesia can be found in various sectors. One of the triggers for corruption is the low awareness that people are also involved in corrupt practices, both as victims and as perpetrators. On the other hand, students as part of the society and future successors of Indonesia have a good understanding of corruption. This article will discuss how formal education institutions can prevent and reduce the number of corruption in society. From the literature study that has been done, the results show that the synergy between educational institutions and students in conducting anti-corruption education can prevent the presence of corrupt practices in Indonesian society, through various methods that adjust to the level of education of these students.
\end{abstract}

Keywords : anti-corruption education, corruption in society, formal education, students

\section{Pendahuluan}

Kata korupsi berasal dari bahasa latin "corruptio" dengan kata kerja "corrumpere" yang dalam bahasa Indonesia dapat diartikan sebagai "busuk", "rusak", "menggoyahkan", "memutar balik", atau "menyogok". Sedangkan menurut hukum di Indonesia, korupsi merupakan praktik melawan hukum yang dilakukan oleh perorangan maupun korporasi dengan maksud untuk memperkaya diri sendiri maupun orang lain, yang merugikan keuangan atau perekonomian negara. Di Indonesia, tindak pidana korupsi telah dikategorikan ke dalam tujuh jenis, yakni kerugian atas keuangan negara, praktik penyuapan, tindak pemerasan, penggelapan dalam jabatan, melakukan kecurangan, konflik kepentingan atas pengadaan barang dan jasa, serta tindakan gratifikasi (Pusat Edukasi Anti Korupsi, 2018a).

Kasus korupsi di Indonesia dapat ditemukan di berbagai sektor. Rata-rata tercatat sebanyak 166 kasus korupsi dengan jumlah 223 terdakwa di setiap tahunnya. Angka tersebut merepresentasikan kasus korupsi yang telah diketahui, di mana jumlah kasus korupsi yang belum terungkap diyakini masih jauh lebih besar dari jumlah 
tersebut. (Pusat Edukasi Anti Korupsi, 2018b). Dari banyaknya kasus korupsi yang ditemukan, para pelaku terdorong untuk melakukan hal tersebut karena dilandasi oleh beberapa hal, baik dari faktor internal maupun eksternal. Pada faktor internal, aspek sosial dan perilaku sang individu itu sendiri menjadi pemicu untuk melakukan korupsi. Sifat tamak, moral yang kurang baik, dan gaya hidup konsumtif yang hadir dari lingkungan keluarga akan secara kuat memberikan suatu dorongan untuk melakukan korupsi. Sedangkan dari faktor eksternal, terdapat aspek sikap masyarakat, aspek ekonomi, aspek politik, maupun aspek dalam organisasi, yang telah mengambil peranan dalam mendorong praktik korupsi di masyarakat (Pusat Edukasi Anti Korupsi, 2018c).

Idealnya, memahami korupsi harus dilakukan oleh seluruh elemen masyarakat, khususnya kalangan pelajar sebagai calon penerus bangsa yang dinilai perlu untuk memahami nilai-nilai anti korupsi dan integritas dengan sedini mungkin. Sejauh ini, pemahaman siswa terhadap tindak korupsi di Indonesia dinilai sudah cukup baik, dan terlihat bahwa adanya hubungan antara tingkat pemahaman korupsi siswa dengan ketaatan mereka terhadap peraturan-peraturan yang berlaku di sekolahnya (Damayanti, Rahman, \& Haboddin, 2018). Namun demikian, Pusat Edukasi Anti Korupsi (2018c) telah memaparkan bahwa tingkat kesadaran masyarakat akan keterlibatan dan tanggung jawab dalam praktik korupsi masih rendah. Masih banyak masyarakat yang tidak menyadari bahwa mereka telah menjadi korban, maupun telah terlibat secara langsung dalam praktik korupsi di lingkungannya.

\section{Permasalahan}

Berdasarkan fenomena yang telah dipaparkan sebelumnya, muncul ketimpangan antara tingginya pemahaman siswa dan rendahnya kesadaran masyarakat terhadap tindakan korupsi di Indonesia. Dengan demikian, artikel ini akan membahas mengenai bagaimana cara institusi pendidikan formal untuk mempersiapkan siswa sebagai bagian dari elemen masyarakat dalam mencegah dan menekan angka korupsi yang ada di masyarakat Indonesia.

\section{Metode}

Para peneliti akan melakukan studi literatur untuk memperkuat perspektif dan menganalisis data menggunakan hasil pemikiran para ahli yang telah melakukan penelitian sebelumnya. Dengan demikian, para peneliti bisa lebih mengetahui mengenai metode penelitian, cara pengaplikasiannya, serta pemahaman yang lebih mendalam atas pemikiran dan apa yang dilakukan oleh peneliti lainnya dalam bidang yang sama (Soewardikoen, 2013).

Melalui studi literatur, penelitian ini akan bermanfaat dalam menjabarkan dan memberikan gambaran terkait beberapa tindakan yang dapat dilakukan oleh siswa dan institusi pendidikan formal dalam menanggapi rendahnya tingkat kesadaran masyarakat terhadap praktik korupsi di Indonesia.

\section{Pembahasan}

Di Indonesia, pada umumnya jenis pendidikan dikelompokan menjadi pendidikan dasar, pendidikan menengah, dan pendidikan tinggi. Dalam membentuk perilaku anti korupsi pada ketiga kelompok jenjang pendidikan tersebut, telah dilakukan pendidikan anti korupsi sebagai sebuah upaya untuk mengajarkan siswa menjadi pribadi yang anti korupsi. Pada institusi pendidikan dasar, guru memiliki peranan penting dalam membentuk karakter siswa menjadi pribadi yang anti korupsi, dengan menanamkan nilai-nilai anti korupsi ke dalam berbagai mata pelajaran sosial, sains, dan bahasa (Widodo, 2019). Selain itu, berdasarkan penelitian yang dilakukan oleh Nurdyansyah (2015), model rekonstruksi sosial akan memaksimalkan keberhasilan pembelajaran anti korupsi. Model tersebut dapat mempermudah siswa dalam memahami makna anti korupsi, menanamkan moral yang baik, serta meningkatkan kepekaan terhadap berbagai fenomena yang tengah terjadi di lingkungannya. Dapat terlihat bahwa sosok pendidik akan mengambil peranan penting pada jenjang pendidikan dasar, dalam konteks pendidikan anti korupsi.

Pada institusi pendidikan menengah, ada beberapa hal yang dinilai dapat membantu kegiatan pendidikan anti korupsi, seperti terdapatnya dukungan sarana dan prasarana, hadirnya partisipasi dari warga sekolah, serta tersedianya dana bantuan sosial (Alfiyati, 2017). Dalam penelitian yang telah dilakukan oleh Sutrisno \& Murdiono (2017), kehadiran modul pendidikan anti korupsi efektif untuk meningkatkan hasil belajar peserta didik, serta efektif dalam meningkatkan sikap anti korupsi peserta didik di institusi pendidikan menengah. Di samping itu, Gurning, Mudjiman, \& Haryanto (2014) telah melakukan penelitian terkait kehadiran kantin kejujuran di sekolah. Dalam penelitian tersebut, dijelaskan bahwa setelah mendapatkan materi terkait anti korupsi di kelas, para siswa dapat langsung menerapkannya di lapangan. Kantin kejujuran hadir sebagai salah satu media pembelajaran siswa yang dirancang untuk menanamkan nilai-nilai anti korupsi, yakni kejujuran, tanggung jawab, keberanian, keadilan, keterbukaan, disiplin, kesederhanaan, kerja keras, serta kepedulian. Dari kedua penelitian tersebut, terlihat bahwa 
selain mendapatkan teori-teori di kelas, siswa diarahkan untuk melakukan praktik melalui sarana dan prasarana yang dihadirkan sebagai media pendidikan anti korupsi pada institusi pendidikan menengah.

Selanjutnya pada tingkat pendidikan tinggi, di mana seluruh peserta didik dan anggota pendidik memiliki kewajiban untuk melaksanakan Tri Dharma Perguruan Tinggi, antara lain pendidikan, penelitian, dan pengabdian kepada masyarakat (Faizal, Fradika, \& Suyono, 2019). Pada poin-poin yang terkandung dalam Tri Dharma Perguruan Tinggi, peneliti menemukan bahwa pendidikan anti korupsi dapat diimplementasikan ke dalam ketiga poin yang terkandung di dalamnya. Pada poin pendidikan, implementasinya akan menyerupai apa yang telah dilakukan pada institusi pendidikan dasar dan menengah, seperti contohnya dengan mewajibkan mata kuliah hukum terkait tindak pidana korupsi (Darmoko, 2018).

Untuk poin penelitian dapat disinergikan dengan poin pengabdian kepada masyarakat, yang dalam praktiknya dapat tertuang dalam program kreativitas mahasiswa. Hal tersebut telah dilakukan oleh Hastuti, Rohmadi, \& Saddhono (2018), yang memberikan penjabaran terkait bahaya korupsi kepada siswa sekolah menengah pertama. Adapun kegiatan ini mampu memberikan pemahaman baik kepada siswa maupun guru, sebagai salah satu upaya dalam mengurangi praktik korupsi sejak dini. Terlepas dari itu, Darmoko (2018) menyebutkan bahwa institusi pendidikan tinggi juga dapat berperan langsung dalam menekan munculnya praktik korupsi, dengan melakukan sosialiasi dan memberlakukan pencabutan gelar bagi para lulusan yang terbukti melakukan praktik korupsi. Adapun dari beberapa literatur yang telah dipaparkan, dapat dirumuskan skema pendidikan anti korupsi yang dapat diberikan institusi pendidikan kepada para siswa dengan menyesuaikan pada jenjang pendidikannya, seperti yang terpaparkan pada tabel 1 berikut ini.

Tabel 1. Skema pendidikan anti korupsi berdasarkan jenjang pendidikan siswa

\begin{tabular}{|l|c|c|c|}
\hline \multicolumn{1}{|c|}{ Metode } & $\begin{array}{c}\text { Teori di } \\
\text { Kelas }\end{array}$ & $\begin{array}{c}\text { Simulasi di } \\
\text { Sekolah }\end{array}$ & $\begin{array}{c}\text { Praktik di } \\
\text { Lapangan }\end{array}$ \\
\hline Dasar & $\checkmark$ & & \\
\hline Menengah & $\checkmark$ & $\checkmark$ & \\
\hline Tinggi & $\checkmark$ & $\checkmark$ & $\checkmark$ \\
\hline
\end{tabular}

Dapat terlihat bahwa institusi pendidikan formal memegang peranan penting terhadap pencegahan tindak korupsi di Indonesia. Hal ini dikarenakan institusi tersebut memiliki peranan besar dalam mendidik para siswa yang merupakan bagian dari elemen masyarakat, yang nantinya akan bersinergi dengan institusi itu sendiri dalam memerangi korupsi di Indonesia. Artikel ini telah memaparkan praktik-praktik yang dapat dilakukan oleh siswa dan berbagai institusi pendidikan formal untuk mencegah munculnya tindak korupsi di masyarakat. Artikel ini juga dapat berperan sebagai contoh dalam melakukan studi literatur terkait bagaimana pendidikan anti korupsi dapat diimplementasikan di masyarakat Indonesia.

\section{Kesimpulan}

Berdasarkan penelitian yang telah dilakukan, dapat ditarik kesimpulan bahwa sinergi antara institusi pendidikan formal dan para siswa dalam melakukan pendidikan anti korupsi dapat mencegah hadirnya praktik korupsi di masyarakat. Pemberlakuan pendidikan anti korupsi terhadap siswa dapat dilakukan dengan berbagai metode yang menyesuaikan pada jenjang pendidikannya. Pada pendidikan dasar, siswa akan dikenalkan pada nilai-nilai anti korupsi seperti kejujuran, tanggung jawab, keberanian, keadilan, keterbukaan, disiplin, kesederhanaan, kerja keras, dan kepedulian, melalui model rekonstruksi sosial yang telah ditanamkan ke dalam mata pelajaran sosial, sains, dan bahasa. Pada pendidikan menengah, siswa akan dibiasakan untuk mengimplementasikan nilai-nilai anti korupsi menggunakan berbagai sarana dan prasarana pendukung dalam bentuk simulasi. Di lingkup pendidikan tinggi, peserta didik yang sudah mendapatkan pemahaman akan nilai-nilai anti korupsi akan mengimplementasikan langsung di masyarakat, sebagai upaya dalam memenuhi Tri Dharma Perguruan Tinggi. Selain itu, pihak institusi juga dapat melakukan kontrol dengan memberlakukan pemberian sanksi terhadap alumninya yang terbutki melakukan tindak korupsi. Dengan demikian, institusi pendidikan formal dapat memberikan pendidikan anti korupsi kepada siswa yang akhirnya dapat terserap ke dalam masyarakat sebagai langkah untuk meningkatkan pemahaman terhadap tindak korupsi di Indonesia. 


\section{Saran Pengembangan}

Untuk pengembangan berikutnya, diharapkan seluruh pihak yang terlibat dapat mempraktikan apa yang telah disampaikan dan menguji seberapa besar efektivitas dari metode yang telah dipaparkan di dalam artikel ini.

\section{Ucapan Terima Kasih}

Terima kasih yang sebesar-besarnya kami ucapkan kepada Direktorat Pengembangan Pembelajaran Universitas Telkom yang telah mengadakan Kompetisi Anti Korupsi 2019, yang telah melandasi terealisasinya kegiatan penelitian ini.

\section{Daftar Pustaka}

Alfiyati, A. (2017). Implementasi Program Pendidikan Anti Korupsi di SMA Negeri 6 Yogyakarta. Jurnal Kebijakan Pendidikan, 6(3), 289-302. Diambil dari http://journal.student.uny.ac.id/ojs/index.php/sakp/article/view/9254

Damayanti, R., Rahman, F., \& Haboddin, M. (2018). Menggali Pemahaman Pelajar Tentang Korupsi. Gorontalo Journal of Government and Political Studies, 1(2), 63-77. https://doi.org/10.32662/gjgops.v1i2.340

Darmoko, M. (2018). Kontrol Korupsi Melalui Perguruan Tinggi. In Seminar Nasional UII Yogyakarta (hal. 215220). Diambil dari https://dspace.uii.ac.id/handle/123456789/11449

Faizal, M., Fradika, D., \& Suyono, R. E. (2019). Executive Legislator : Menilik Cara Kerja Legislator Keluarga Mahasiswa. Bandung: Tel-U Press.

Gurning, N. L. M., Mudjiman, H., \& Haryanto, S. (2014). Implementasi Pendidikan Anti Korupsi melalui Warung Kejujuran di SMP Keluarga Kudus. Jurnal Teknologi Pendidikan dan Pembelajaran, 2(1), 93-102. Diambil dari https://jurnal.fkip.uns.ac.id/index.php/tp/article/view/3670

Hastuti, S., Rohmadi, M., \& Saddhono, K. (2018). Internalisasi Pendidikan Karakter dan Anti Korupsi dalam Mata Pelajaran pada Sekolah Menengah Pertama di Kabupaten Boyolali. Preprint. https://doi.org/10.31227/osf.io/nbjpv

Nurdyansyah. (2015). Model Social Reconstruction Sebagai Pendidikan Anti Korupsi pada Pelajaran Tematik di Madrasah Ibtida'iyah Muhammadiyah 1 Pare. Halaqa: Jurnal Pendidikan dan Keislaman, 14(1), 13-23. Diambil dari http://eprints.umsida.ac.id/1620/

Pusat Edukasi Anti Korupsi. (2018a). Apa itu Korupsi? Diambil 19 November 2019, dari https://aclc.kpk.go.id/materi/berpikir-kritis-terhadap-korupsi/infografis/apa-itu-korupsi

Pusat Edukasi Anti Korupsi. (2018b). Kasus-Kasus Korupsi di Indonesia. Diambil 19 November 2019, dari https://aclc.kpk.go.id/materi/berpikir-kritis-terhadap-korupsi/infografis/kasus-kasus-korupsi-di-indonesia

Pusat Edukasi Anti Korupsi. (2018c). Penyebab Korupsi. Diambil 19 November 2019, dari https://aclc.kpk.go.id/materi/berpikir-kritis-terhadap-korupsi/infografis/penyebab-korupsi

Soewardikoen, D. W. (2013). Metodologi Penelitian Visual, dari Seminar ke Tugas Akhir. Bandung: Dinamika Komunika.

Sutrisno, S., \& Murdiono, M. (2017). Pengembangan Modul Pendidikan Anti Korupsi pada Mata Pelajaran Pendidikan Pancasila dan Kewarganegaraan untuk Kelas X Sekolah Menengah Atas. Harmoni Sosial: Jurnal Pendidikan IPS, 4(1), 55-66. https://doi.org/10.21831/hsjpi.v4i1.9789

Widodo, S. (2019). Membangun Pendidikan Anti Korupsi di Sekolah Dasar. JPD: Jurnal Pendidikan Dasar, 10(1), 35-44. Diambil dari http://journal.unj.ac.id/unj/index.php/jpd/article/view/11142 